\title{
Impact of a stepwise introduction of smoke-free legislation on the rate of preterm births: analysis of routinely collected birth data
}

\author{
(c) (1) (8) OPEN ACCESS
}

\author{
Bianca Cox PhD student ${ }^{1}$, Evelyne Martens MSc student ${ }^{2}$, Benoit Nemery professor ${ }^{3}$, Jaco \\ Vangronsveld professor ${ }^{1}$, Tim S Nawrot associate professor of environmental epidemiology ${ }^{13}$
}

${ }^{1}$ Centre for Environmental Sciences, Hasselt University, Agoralaan gebouw D, 3590 Diepenbeek, Belgium; ${ }^{2}$ Study Centre for Perinatal Epidemiology, Brussels, Belgium; ${ }^{3}$ Department of Public Health, University of Leuven (KU Leuven), Leuven, Belgium

\begin{abstract}
Objective To investigate the incidence of preterm delivery in the Belgian population after implementation of smoke-free legislation in three phases (in public places and most workplaces January 2006, in restaurants January 2007, and in bars serving food January 2010).

Design Logistic regression analyses on routinely collected birth data from January 2002 to December 2011

Setting Flanders, Belgium.

Population All live born singleton births delivered at 24-44 weeks of gestation ( $n=606877$, with $n=448520$ spontaneous deliveries).

Main outcome measures Preterm birth (gestational age $<37$ weeks).

Results We found reductions in the risk of preterm birth after the introduction of each phase of the smoking ban. No decreasing trend was evident in the years or months before the bans. We observed a step change in the risk of spontaneous preterm delivery of $-3.13 \%(95 \%$ $\mathrm{Cl}-4.37 \%$ to $-1.87 \%$; $\mathrm{P}<0.01$ ) on 1 January 2007 (ban on smoking in restaurants), and an annual slope change of $-2.65 \%(-5.11 \%$ to $-0.13 \%$; $\mathrm{P}=0.04$ ) after 1 January 2010 (ban on smoking in bars serving food). The analysis for all births gave similar results: a step change of $-3.18 \%$ $(-5.38 \%$ to $-0.94 \% ; P<0.01)$ on 1 January 2007 , and an annual slope change of $-3.50 \%(-6.35 \%$ to $-0.57 \% ; P=0.02)$ after 1 January 2010. These changes could not be explained by personal factors (infant sex, maternal age, parity, socioeconomic status, national origin, level of urbanisation); time related factors (underlying trends, month of the year, day of the week); or population related factors (public holidays, influenza epidemics, and short term changes in apparent temperature and particulate air pollution).

Conclusion Our study shows a consistent pattern of reduction in the risk of preterm delivery with successive population interventions to restrict smoking. This finding is not definitive but it supports the notion that smoking bans have public health benefits from early life.
\end{abstract}

\section{Introduction}

It is well established that active maternal smoking during pregnancy impairs fetal growth ${ }^{12}$ and shortens gestation. ${ }^{2-4}$ Moreover, secondhand smoke has also been found to affect birth outcomes. $^{235-13}$ A meta-analysis on passive smoking during pregnancy and fetal health estimated that exposure of non-smoking pregnant women to secondhand smoke reduces mean birth weight by $33 \mathrm{~g}$ or more, and increases the risk of a birth weight below $2500 \mathrm{~g}$ by $22 \% .{ }^{11}$ A clear effect on gestational length was not found, ${ }^{11}$ although many studies did report a significant association between secondhand smoke and premature birth. ${ }^{23-101213}$ A large body of evidence suggests that low birth weight $(<2500 \mathrm{~g})^{14} 15$ and premature birth $(<37$ weeks gestation $)^{16-18}$ are important risk factors for morbidity and mortality in childhood ${ }^{1517}$ and in adulthood. ${ }^{14} 16$

Interventions to reduce exposure to secondhand smoke have been found to reduce the incidence of cardiovascular diseases, ${ }^{19-23}$ but only a few studies have examined the effect on pregnancy outcomes. ${ }^{72425}$ To our knowledge, only two studies have investigated the impact of a smoking ban on birth weight and preterm birth. ${ }^{24}{ }^{25}$ However, one study did not take into account time trends, ${ }^{24}$ and both studies examined the effect on outcomes of only a single change in legislation.

In Belgium, smoke-free legislation was implemented in different phases. ${ }^{26}$ The first phase, implemented on 1 January 2006, required all public places and workplaces, except for the catering industry, to be smoke-free. The legislative ban on smoking in restaurants was introduced on 1 January 2007, while for bars serving food, smoke-free legislation was implemented on 1 January 2010. These successive steps in legislation gave us the 
opportunity to investigate possible stepwise changes in preterm delivery.

\section{Methods \\ Data collection}

Data on births in Flanders during the period 2002-11 were obtained from the Study Centre for Perinatal Epidemiology (SPE). Flanders is the Dutch speaking northern part of Belgium with about six million inhabitants, and it has 68 maternity-obstetric units, where almost all (99\%) births occur. ${ }^{27}$ For each newborn of at least $500 \mathrm{~g}$, an official and coded perinatal form is completed (most often by the midwife) which includes information on ultrasound corrected gestational age. The form is sent to the SPE, where all data are controlled by an error detection program and feedback is provided. ${ }^{28}$ A qualitative assessment of the SPE data shows that there is less than 5\% discrepancy between electronic data and data derived from medical files. ${ }^{28}$ A unique feature of the data is that $99.8 \%$ of all births (of $\geq 500 \mathrm{~g}$ ) in Flanders are registered. Data concerning education and national origin of the mother are obtained through linkage of the medical birth certificates of the SPE with official birth declarations. However, this linkage is only available until 2009.

We limited our analyses to singleton, live born infants delivered at 24-44 weeks of gestation. The primary outcomes for this study were the risks of spontaneous and overall preterm delivery. Changes in the risk of infants born small for gestational age, low birth weight, and birth weight were secondary outcomes. Spontaneous deliveries were obtained by excluding those births that were indicated as having been induced because of medical or other (unknown) reasons. Preterm delivery was defined as a gestational age below 37 completed weeks. Preterm births were further classified as mild (34-36 weeks), moderate (32-33 weeks) and extreme ( $<32$ weeks) preterm. Small for gestational age was defined as a birth weight below the 10th centile for the gestational age and sex of the baby. Low birth weight was defined as below $2500 \mathrm{~g}$. Maternal age was categorised as $<25$, $25-34$, and $\geq 35$ years. The degree of urbanisation of maternal residence was dichotomised into urban or semi-urban versus rural municipalities. ${ }^{29}$ Maternal residence was also used to create three classes of socioeconomic status at the municipality level, based on salary level, economic activity, degree of unemployment, and equipment level (facilities) of houses (such as percentage with central heating). ${ }^{30}$

Data on influenza epidemics in Belgium were provided by the National Influenza Centre. ${ }^{31}$ This centre collects information on circulating influenza viruses, whereas the Unit of Health Services Research of the Institute of Public Health collects data on visit rates for influenza-like illnesses from a representative network of general physicians. Influenza epidemics are defined as a consultation rate above the epidemic threshold (138/100 000 inhabitants).

Mean daily temperature and relative humidity data were provided by the Belgian Royal Meteorological Institute and were used to calculate mean apparent temperature, an index of human discomfort. ${ }^{32} \mathrm{We}$ used data from a central and representative station in Uccle (Brussels, Belgium), because the region of Flanders is uniform for temperature, as a result of small altitudinal and latitudinal gradients. Data on daily mean particulate matter $\left(\mathrm{PM}_{10}\right)$ were obtained from the Belgian Interregional Environment Agency (IRCEL), which monitors ambient air quality with a dense network of automatic monitoring sites. ${ }^{33}$
Because data on education and national origin of mothers were only available until 2009 , they were used in a sensitivity analysis. Education level was defined as low (lower secondary education or less), medium (secondary education completed), or high (higher education). National origin of the mother was categorised as European, Asian, Middle Eastern, African, North American, South American, or Australian.

The ethical committee of Hasselt University approved the study.

\section{Statistical analysis}

We explored the time trend in preterm delivery by using a smoothing spline on monthly rates with 10 degrees of freedom in the SAS GAM procedure. For the main analysis, based on individual level data, we used logistic regression models to test the hypothesis that there were changes in spontaneous and overall preterm delivery immediately after the introduction of the different phases of smoke-free legislation. The minimum duration of pre-legislative data was four years (that is, before the first phase of the legislation, on 1 January 2006) and the minimum amount of post-legislative data was two years (that is, after the start of the third phase of the legislation, on 1 January 2010).

The models allowed for an underlying trend throughout the study period and were adjusted for infant sex, maternal age, parity, socioeconomic status (municipality level or individual level (in sensitivity analysis)), national origin (in sensitivity analysis), level of urbanisation of maternal residence, month of the year, day of the week, public holidays, influenza epidemics, apparent temperature, and $\mathrm{PM}_{10}$ levels. For apparent temperature and for $\mathrm{PM}_{10}$, we calculated the average exposure on the day of delivery and the day before, and we allowed for non-linear associations with preterm birth by using natural cubic splines. ${ }^{34}$ We used four degrees of freedom for apparent temperature and two degrees of freedom for $\mathrm{PM}_{10}$.

The immediate effect of smoke-free legislation was modelled as a step function (step change), including a binary indicator variable which takes a value of 1 when the ban is present and 0 otherwise, while the gradual effects were studied with an interaction term between the indicator variable and time (trend or slope change). We started by examining the effect of the three legislation phases by using separate models for each phase, including either the step change or the slope change into the model. Then, we entered the three phases in the same model: in a first model we included only the step changes of the three phases, and in a second model we included only the slope changes. Finally, we started with a full model including the three step changes and the three slope changes and in subsequent models we removed the least significant factors one at a time. From the above models, we selected the best performing model based on the Akaike Information Criterion statistic.

We also tested interaction terms to examine potential differences in the immediate and gradual effects of the smoking bans between subgroups, after also allowing for different pre-legislation trends. The beta coefficients derived from the logistic regression models for the step and slope changes were converted into percentage changes using the formula $100 \times(\exp (\beta)-1)$. In sensitivity analyses, models were additionally adjusted for education and national origin of the mother (both available until 2009).

In a secondary analysis, we investigated the risk of small for gestational age and low birth weight by using the same methods as described above, and we analysed average birth weight as a continuous variable by using linear regression models. All the 
analyses were performed by using SAS version 9.2 (SAS Institute, Cary, NC, USA).

\section{Results}

There were 631794 registered deliveries in Flanders during the study period (2002-11). We excluded 24917 (3.9\%) births which did not satisfy the inclusion criteria (multiple births, stillbirths, or deliveries before 24 weeks or after 44 weeks). Among the remaining 606877 births, 448520 (73.9\%) were spontaneous deliveries. Detailed characteristics of the study population are presented in the supplementary table on bmj.com. Characteristics for spontaneous and overall deliveries are similar. Among the spontaneous births, $51.4 \%$ were boys, median (10-90th centile) maternal age was 29.5 (23.6-35.8) years, and median birth order was 2 (1-3). Table $1 \Downarrow$ provides details of maternal age, preterm birth, birth weight, small for gestational age, and low birth weight by year. During the study period, a total of 32123 (7.2\%) spontaneous deliveries occurred before 37 weeks of gestation. Of these, $25010(77.9 \%)$ were mild preterm, 3518 (10.9\%) were moderate preterm, and 3595 (11.2\%) were extreme preterm. A total of 44225 (9.9\%) spontaneous births were small for gestational age, and 23570 (5.3\%) were low birth weight. Median (10-90th centile) birth weight was 3370 (2835-3950) $\mathrm{g}$ among full term infants and 2520 (1490-3150) g among preterm infants.

The figure $\Downarrow$ shows the smoothed curve of the crude percentage of spontaneous preterm deliveries by month of birth as an exploratory analysis. From the figure, the preterm birth rate was relatively stable before the first smoke-free legislation, followed by a decline in the year after the introduction of the first phase of the legislation (workplace). The decline persisted after the second smoking ban (restaurants), although this was partially reversed in the first months of 2008. A second sharp decline can be noticed in 2010, coinciding with the third phase of the legislation (bars serving food).

We further studied the impact of the smoking bans by using logistic regression models. Table $2 \Downarrow$ shows the immediate (step) and gradual (slope) changes in preterm birth risk following the introduction of the different phases of smoke-free legislation, after adjustment for the potential confounders. We did not find effect modification by personal characteristics (infant sex, maternal age, parity), so final models did not include interactions terms with these variables. There was no significant baseline trend in the risk of spontaneous preterm delivery $(-0.16 \%$ (95\% confidence interval $-1.18 \%$ to $0.86 \%$ ) per year), whereas the underlying trend for overall preterm deliveries increased $(0.99 \%$ $(0.03 \%$ to $1.96 \%)$ per year). Although table $2 \Downarrow$ shows reduced risks after each of the three phases of smoke-free legislation, a comparison of models indicates that the second and third legislation phases (ban in restaurants and in bars serving food respectively) were followed by the largest changes in preterm birth. The model producing the best fit consisted of a step change on 1 January 2007 and a slope change after 1 January 2010 (table $2 \Downarrow$ ). The second legislation phase was followed by a step change in the risk of spontaneous preterm delivery of $-3.13 \%$ $(-4.37 \%$ to $-1.87 \%$; $\mathrm{P}<0.01)$ on 1 January 2007 , whereas the third phase was followed by an annual slope change of $-2.65 \%$ $(-5.11 \%$ to $-0.13 \%$; $\mathrm{P}=0.04)$ after 1 January 2010 . The analysis for overall preterm delivery showed a step change in the risk of $-3.18 \%(-5.38 \%$ to $-0.94 \%$; $\mathrm{P}<0.01)$ on 1 January 2007 , and an annual slope change in the risk of $-3.50 \%$ ( $-6.35 \%$ to $-0.57 \% ; \mathrm{P}=0.02$ ) after 1 January 2010 . To put this in perspective, these changes correspond to a reduction of six preterm births per 1000 deliveries over the five study years (after 2007).

Adding data on education and national origin of the mother (available until 2009) to the final model produced similar estimates for the step change in 2007 for spontaneous preterm delivery $(-1.98 \%(-3.40 \%$ to $-0.54 \% ; \mathrm{P}<0.01))$ as well as for overall preterm delivery $(-3.23 \%(-5.62 \%$ to $-0.77 \% ; \mathrm{P}=0.01))$. We did not observe significant effects of the smoking bans on the risk of low birth weight or small for gestational age in the population, nor on average birth weight.

\section{Discussion}

We found significant reductions in the rate of preterm births after the implementation of different types of smoking bans, whereas no such decrease was evident in the years or months before these bans. Our results confirm those from a recent study. ${ }^{25}$ Given that even a mild reduction in gestational age has been linked to adverse health outcomes in early and later life, our study has important public health implications. Indeed, a Swedish study found that, even among those born late preterm (34-36 weeks), preterm birth was associated with a $31 \%(13 \%$ to $50 \%$ ) increase in mortality in young adulthood. ${ }^{16}$

As smoke-free legislation in Belgium was implemented in different phases, we were able to demonstrate a consistent pattern of changes in preterm delivery with stepwise reductions over the different enforcements. Hill proposed both internal and external consistency as one of the most important criteria of causality. ${ }^{35}$ Although a single epidemiological study cannot prove causality, we believe that one strength of our study is that the changes showed an internally consistent pattern, with rates of preterm deliveries decreasing after each of the three smoking bans. The smoking ban at work was followed by a less marked reduction in preterm deliveries than the later ban in restaurants. It might be that the implementation of non-smoking regulation at work took place more gradually than the other bans, thus perhaps explaining why the effects of the latter were stronger (or more obvious in the analysis).

\section{Interpretation of results}

This study must be viewed as an investigation of the possible impact of a "population intervention" rather than an investigation of changes in individual behaviour. It is possible that unmeasured confounders were responsible for the observed changes. Nevertheless, it is hard to conceive of a factor that could change the population risk of preterm births after the introduction of the different successive smoking bans. We adjusted for many potential confounders both at the individual level, including maternal education and national origin, and at the population level, including potential short term changes in air pollution and influenza epidemics.

It is unlikely that our observations could be explained by abrupt changes in therapeutic strategies coinciding with the smoking bans. Nevertheless, we collected data on the prescription of atosiban and on cervical cerclage treatment from a social security organisation covering $42 \%$ of the population. Atosiban is an inhibitor of oxytocin and vasopressin and is specifically used to halt premature labour. Cervical cerclage is used for the treatment of cervical incompetence, a condition where the cervix has become slightly open and there is a risk of miscarriage. There were no substantial changes in the use of either treatment during the study period: the number of women given atosiban varied from 59 per 1000 deliveries (846 prescriptions per 1000 deliveries) in 2005 to 63 per 1000 (753 prescriptions per 1000 deliveries) in 2011, and the number of cervical cerclages varied 
from 11 per 1000 deliveries in 2002 to 8 per 1000 deliveries in 2011.

One could object that the effects of the smoking bans were apparent only on the rate of preterm births, and we acknowledge that the absence of an effect on birth weight and small for gestational age reduces the strength and diminishes the plausibility of our observation. Although some overlap exists in risk factors for prematurity and small for gestational age, several investigators recommend treating these outcomes as distinct aetiologies. ${ }^{36}$ Conversely, the observed dissociation between an effect on triggering labour and on birth weight may point to the need for further research on other potential triggering factors. Changes in birth weight and small for gestational age at the population level might be a longer term reflection of detrimental effects of active or passive smoking during pregnancy while preterm delivery might have a discrete trigger component, as suggested by studies on short term effects of air pollution and temperature. ${ }^{38-42}$

Similar to our results, a study on the impact of the Irish workplace smoking ban on birth weight and preterm birth found a protective effect only on the latter outcome..$^{24}$ Although their analysis was limited to a comparison of rates one year before and after the ban, they even found an increase in the risk of low birth weight. Although a meta-analysis concluded that passive smoking does not affect preterm birth, ${ }^{11}$ many studies did report a significant association between exposure to secondhand smoke and premature birth. ${ }^{23}$ 5-10 1213 In a study of 389 non-smoking mothers, Jaakkola and colleagues ${ }^{9}$ found that environmental tobacco smoke had stronger effects on preterm delivery than on low birth weight and small for gestational age — that is, a 1 $\mu \mathrm{g} / \mathrm{g}$ increase in hair nicotine concentration was associated with an increase in adjusted odds ratio of 1.22 (1.07 to 1.39) for preterm delivery compared with 1.06 (0.96 to 1.17$)$ and 1.04 (0.92 to 1.19) for low birth weight and small for gestational age. Previous investigations of the health benefits at the population level of smoke-free legislation have focused primarily on the incidence of cardiovascular morbidity ${ }^{20}$ which is known to be triggered by various factors. ${ }^{43}$ Further evidence of population health gains comes from observations of reduced asthma hospitalisation by $18 \%$ after the introduction of smoke-free legislation. ${ }^{44}$ The plausibility of the favourable effects of smoking bans rests on well known effects of active and passive smoking based on animal and human studies. ${ }^{45}$

\section{Limitations of study}

The main limitation, common to most studies on smoking bans, ${ }^{19}{ }^{21-23} 44$ is that we do not have data on individual smoking status, neither active nor passive. The birth records also did not allow us to address other known risk factors for preterm birth, such as marital status, psychosocial stressors, maternal weight, occupation, and nutrition. However, the objective of our study was to describe the possible health impact of population based interventions, such as smoking bans, on preterm births, rather than to investigate the effects of personal exposures.

The observed effects may be due to reduced exposure of pregnant women to secondhand smoke at the workplace or in public places ${ }^{46}$ but they may also reflect an overall reduction in tobacco consumption. Indeed, smoke-free legislation may stimulate smokers to establish total smoking bans in their homes ${ }^{47}$ and has resulted in increased smoking cessation, ${ }^{48-50}$ also among pregnant women. ${ }^{24}{ }^{25}$ The Belgian Health Interview suggests that the total population prevalence of active smoking in Belgium was relatively stable from 1997 to 2004, but decreased significantly from 2004 to $2008 .{ }^{52}$ More specifically, the percentage of female smokers in Flanders was close to $22 \%$ in 1997, 2001, and 2004, whereas in 2008 the percentage was only $17.9 \%$. The prevalence of daily smoking among Flemish women decreased from $18.5 \%$ in 2004 to $15.3 \%$ in 2008 and the prevalence of heavy smoking ( $\geq 20$ cigarettes a day) declined from $7.7 \%$ to $4.9 \%$. A survey in a random sample of 3017 women in Flanders between May 2008-09 indicated that 22.7\% $(21.0 \%$ to $24.6 \%)$ of the women were active smokers before pregnancy and $12.3 \%$ (10.9\% to $13.8 \%$ ) continued smoking during pregnancy. ${ }^{53}$ Exposure to secondhand smoke during pregnancy was reported by $10.6 \%(9.3 \%$ to $12.0 \%)$ of the women.

\section{Conclusions}

Further proof of our population based observations could be provided in countries where smoking bans have been relaxed, as in the Netherlands. ${ }^{54}$ However, along with the prospectively gained evidence on smoking and its detrimental effects on pregnancy complications, our study supports the public health benefit of smoking bans early in life.

We thank Professor Gyselaers (department of obstetrics, East-Limburg Hospital, Genk, and faculty of life sciences and medicine, Hasselt University) for his useful comments. We thank Dr M Callens, research director of $\mathrm{CM}$ social security organisation, for providing figures on atosiban and cervical cerclage.

Contributions: TSN and BC designed the study. BC did the statistical analysis and wrote, together with TSN, the first draft of the paper. EM collected the data. All authors contributed to the discussion and interpretation of the data and the writing of the article, and approved the final version of the manuscript.

Funding: The Study Centre for Perinatal Epidemiology is financed and commissioned by the Flemish Centre for Care and Health (Agentschap Zorg en Gezondheid). This study was supported by grants from the Flemish Scientific fund (FWO: G.0.873.11.N.10/1.5.158.09.N.00), ERC starting grant (ENVIRONAGE), and Hasselt University Fund (BOF).

Competing interests: All authors have completed the ICMJE uniform disclosure form at www.icmje.org/coi_disclosure.pdf (available on request from the corresponding author) and declare: no financial relationships with any organisations that might have an interest in the submitted work in the previous three years and no other relationships or activities that could appear to have influenced the submitted work Ethical approval: The ethical committee of Hasselt University approved the study.

Data sharing: No additional data available.

Kramer MS. Determinants of low birth weight: methodological assessment and meta-analysis. Bull World Health Organ 1987;65:663-737.

2 Windham GC, Hopkins B, Fenster L, Swan SH. Prenatal active or passive tobacco smoke exposure and the risk of preterm delivery or low birth weight. Epidemiology 2000;11:427-33. Fantuzzi G, Aggazzotti G, Righi E, Facchinetti F, Bertucci E, Kanitz S, et al. Preterm delivery and exposure to active and passive smoking during pregnancy: a case-control study from Italy. Paediatr Perinat Epidemiol 2007;21:194-200.

4 Shah NR, Bracken MB. A systematic review and meta-analysis of prospective studies on the association between maternal cigarette smoking and preterm delivery. Am J Obstet Gynecol 2000;182:465-72.

5 Ahluwalia IB, Grummer-Strawn L, Scanlon KS. Exposure to environmental tobacco smoke and birth outcome: increased effects on pregnant women aged 30 years or older. Am J Epidemiol 1997;146:42-7.

6 Crane JMG, Keough M, Murphy P, Burrage L, Hutchens D. Effects of environmental tobacco smoke on perinatal outcomes: a retrospective cohort study. BJOG 2011;118:865-71.

7 EI-Mohandes AAE, Kiely M, Blake SM, Gantz MG, El-Khorazaty MN. An intervention to reduce environmental tobacco smoke exposure improves pregnancy outcomes. Pediatrics 2010;125:721-8.

8 Hanke W, Kalinka J, Florek E, Sobala W. Passive smoking and pregnancy outcome in central Poland. Hum Exp Toxicol 1999;18:265-71.

9 Jaakkola JJ, Jaakkola N, Zahlsen K. Fetal growth and length of gestation in relation to prenatal exposure to environmental tobacco smoke assessed by hair nicotine concentration. Environ Health Perspect 2001;109:557-61.

10 Kharrazi M, DeLorenze GN, Kaufman FL, Eskenazi B, Bernert JTJ, Graham S, et al. Environmental tobacco smoke and pregnancy outcome. Epidemiology 2004;15. 


\section{What is already known on this topic}

Despite growing evidence that secondhand smoke has a negative impact on pregnancy duration and birth weight, few studies have shown a beneficial impact of smoke-free legislation on pregnancy outcomes

\section{What this study adds}

Stepwise implementation of smoke-free legislation in Belgium allowed the demonstration of successive reductions in preterm deliveries which persisted after the implementation of the different legislation phases

The largest reductions in preterm birth coincided with the implementation of the second and the third phase of the legislation (smoking ban in restaurants and in bars serving food, respectively)

Even a small relative decline in preterm deliveries can have important public health benefits

11 Leonardi-Bee J, Smyth A, Britton J, Coleman T. Environmental tobacco smoke and fetal health: systematic review and meta-analysis. Arch Dis Child Fetal Neonatal Ed 2008;93:F351-F361.

12 Lee BE, Hong YC, Park H, Lee JT, Kim YJ, Kim JY, et al. Maternal exposure to environmental tobacco smoke (ETS) and pregnancy outcomes in prospective cohort study: Isee-264. Epidemiology 2003;14.

13 Ashford K, Hahn E, Hall L, Rayens M, Noland M, Ferguson J. The effects of prenatal secondhand smoke exposure on preterm birth and neonatal outcomes. J Obstet Gynecol Neonatal Nurs 2010;39:525-35.

14 Barker DJP, Godfrey KM, Gluckman PD, Harding JE, Owens JA, Robinson JS. Fetal nutrition and cardiovascular disease in adult life. Lancet 1993:341:938-41.

15 McCormick MC. The contribution of low birth weight to infant mortality and childhood morbidity. N Engl J Med 1985;312:82-90.

16 Crump C, Sundquist K, Sundquist J, Winkleby MA. Gestational age at birth and mortality in young adulthood. JAMA 2011;306:1233-40.

17 Engle WA, Tomashek KM, Wallman C, Committee on Fetus and Newborn. "Late-preterm" infants: a population at risk. Pediatrics 2007:120:1390-401.

18 McIntire DD, Leveno KJ. Neonatal mortality and morbidity rates in late preterm births compared with births at term. Obstet Gynecol 2008;111:35-41.

19 Barone-Adesi F, Vizzini L, Merletti F, Richiardi L. Short-term effects of Italian smoking regulation on rates of hospital admission for acute myocardial infarction. European Heart Journal 2006;27:2468-72.

20 Meyers DG, Neuberger JS, He J. Cardiovascular effect of bans on smoking in public places: a systematic review and meta-analysis. J Am Coll Cardiol 2009;54:1249-55.

21 Sargent R, Shepard R, Glantz S. Reduced incidence of admissions for myocardial infarction associated with public smoking ban: before and after study. BMJ 2004;328:977-80.

22 Sims M, Maxwell R, Bauld L, Gilmore A. Short term impact of smoke-free legislation in England: retrospective analysis of hospital admissions for myocardial infarction. BMJ 2010;340:c2161.

23 Centers for Disease Control and Prevention. Reduced hospitalizations for acute myocardial infarction after implementation of a smoke-free ordinance-City of Pueblo, Colorado, 2002-2006. JAMA 2009;301:480-3.

24 Kabir Z, Clarke V, Conroy R, McNamee E, Daly S, Clancy L. Low birthweight and preterm birth rates 1 year before and after the Irish workplace smoking ban. BJOG 2009;116:1782-7.

25 Mackay DF, Nelson SM, Haw SJ, Pell JP. Impact of Scotland's smoke-free legislation on pregnancy complications: retrospective cohort study. PLoS Med 2012;9:e1001175.

26 Vlaamse Liga tegen Kanker. Gedwongen meeroken-De wet [Passive smoking-the law]. 2011. www.tegenkanker.be/content/wetgeving.

27 Keirse MJNC, Hanssens M, Devlieger H. Trends in preterm births in Flanders, Belgium, from 1991 to 2002. Paediatr Perinat Epidemiol 2009:23:522-32.

28 Cammu H, Martens G, Ruyssinck G. Amy JJ. Outcome after elective labor induction in nulliparous women: a matched cohort study. Am J Obstet Gynecol 2002;186:240-4.

29 Van Hecke E, Halleux JM, Decroly JM, Mérenne-Schoumaker B. Woonkernen en stadsgewesten in een verstedelijkt België. Sociaal-economische enquête 2001 monografieën. [Residential and urban areas in an urbanized Belgium. Socioeconomic survey 2001 monographs]. 2009. http://statbel.fgov.be/nl/binaries/80325-Mono\%209\% 20Verstedelijking-nl-defapril tcm325-92953.pdf.

30 Dexia Bank NV. Sociaaleconomische typologie van de gemeenten [Socioeconomic typology of the municipalities]. 2007. www.dexia.be/NI/smallsites/research/PublicFinance/ typo.

31 Van Casteren V, Mertens K, Antoine J, Wanyama S, Thomas I, Bossuyt N. Clinical surveillance of the Influenza $A(\mathrm{H} 1 \mathrm{~N} 1) 2009$ pandemic through the network of sentinel general practitioners. Arch Public Health 2010;68:62-7.

32 Kalkstein LS, Valimont KM. An evaluation of summer discomfort in the United States using a relative climatological index. Bull Am Meteorol Soc 1986;7:842-8.

33 Janssen S, Dumont G, Fierens F, Mensink C. Spatial interpolation of air pollution measurements using CORINE land cover data. Atmos Environ 2008;42:4884-903.

34 Harrel FE. Regression modeling strategies: with applications to linear models, logistic regression, and survival analysis . New York: Springer, 2001.

35 Hill AB. The environment and disease: association or causation? Proc $R$ Soc Med 1965;58:295-300.
36 Lang J, Lieberman E, Cohen A. A comparison of risk factors for preterm labor and term small-for-gestational-age birth. Epidemiology 1996;7:369-76.

37 Villar J, Khoury MJ, Finucane FF, Delgado HL. Differences in the epidemiology of prematurity and intrauterine growth retardation. Early Hum Dev 1986;14:307-20.

38 Basu R, Malig B, Ostro BD. High ambient temperature and the risk of preterm delivery Am J Epidemiol 2010;172:1108-17.

39 Dadvand P, Basagaña X, Sartini C, Figueras F, Vrijheid M, de Nazelle A, et al. Climate extremes and the length of gestation. Environ Health Perspect 2011;119:1449-53.

40 Liu S, Krewski D, Shi Y, Chen Y, Burnett R. Association between gaseous ambient air pollutants and adverse pregnancy outcomes in Vancouver, Canada. Environ Health Perspect 2003;111:1773-8

41 Sagiv S, Mendola P, Loomis D, Herring A, Neas L, Savitz D, et al. A time series analysis of air pollution and preterm birth in Pennsylvania, 1997-2001. Environ Health Perspect 2005;113:602-6.

$42 \mathrm{Xu} \mathrm{X}$, Ding H, Wang $\mathrm{X}$. Acute effects of total suspended particles and sulfur dioxides on preterm delivery: a community-based cohort study. Arch Environ Health 1995;50:407-15.

43 Nawrot TS, Perez L, Künzli N, Munters E, Nemery B. Public health importance of triggers of myocardial infarction: a comparative risk assessment. Lancet 2011;377:732-40.

44 Mackay D, Haw S, Ayres JG, Fischbacher C, Pell JP. Smoke-free legislation and hospitalizations for childhood asthma. N Engl J Med 2010;363:1139-45.

45 Schick S, Glantz S. Philip Morris toxicological experiments with fresh sidestream smoke: more toxic than mainstream smoke. Tob Control 2005;14:396-404.

46 Haw SJ, Gruer L. Changes in exposure of adult non-smokers to secondhand smoke after implementation of smoke-free legislation in Scotland: national cross sectional survey. BMJ 2007:335:549.

47 Mons U, Nagelhout GE, Allwright S, Guignard R, van den Putte B, Willemsen MC, et al. Impact of national smoke-free legislation on home smoking bans: findings from the International Tobacco Control Policy Evaluation Project Europe Surveys. Tob Control 2012; [epub ahead of print].

48 Fichtenberg CM, Glantz SA. Effect of smoke-free workplaces on smoking behaviour: systematic review. BMJ 2002;325:188.

49 Gallus S, Zuccaro P, Colombo P, Apolone G, Pacifici R, Garattini S, et al. Smoking in Italy 2005-2006: Effects of a comprehensive National Tobacco Regulation. Prev Med 2007;45:198-201.

50 Cancer Research UK Press release. Smoking ban triggered the biggest fall in smoking ever seen in England. 30-6-2008. http://info.cancerresearchuk.org.

51 Charrier L, Serafini P, Giordano L, Zotti CM. Smoking habits in Italian pregnant women: any changes after the ban? J Public Health Policy 2010;31:51-8.

52 Charafeddine R, Demarest S, Drieskens S, Gisle L, Tafforeau J, Van der Heyden J. Health Interview Survey, Belgium, 1997 - 2001 - 2004 - 2008. Health interview survey interactive analysis. Public Health and Surveillance, Scientific Institute of Public Health, Brussels, Belgium. 2012. www wiv-isp be/epidemio/hisia/index.htm.

53 Hoppenbrouwers K, Roelants M, Guérin C, Van Leeuwen K, Desoete A, Wiersema R Als mama rookt, rookt de baby mee: sociaaleconomische indicatoren en perinatale gezondheidseffecten van gedwongen blootstelling van een Vlaamse geboortecohorte aan tabaksrook tijdens de zwangerschap in de eerste levensweken [lf mom smokes, the baby smokes: socio-economic indicators and perinatal health effects of exposure to tobacco smoke from a Flemish birth cohort during pregnancy in the first weeks of life]. Steunpunt beleidsrelevant onderzoek SWVG: feiten en cijfers 2011;7.

54 Sheldon T. Dutch groups appeal against irresponsible plan to exempt small cafés from smoking ban. BMJ 2010;341:c5503.

Accepted: 16 November 2012

\section{Cite this as: BMJ 2013;346: 4441}

This is an open-access article distributed under the terms of the Creative Commons Attribution Non-commercial License, which permits use, distribution, and reproduction in any medium, provided the original work is properly cited, the use is non commercial and is otherwise in compliance with the license. See: http://creativecommons.org/licenses/bync/2.0/ and http://creativecommons.org/licenses/by-nc/2.0/legalcode. 


\section{Tables}

\begin{tabular}{|c|c|c|c|c|c|c|c|c|c|c|c|c|c|}
\hline \multirow[b]{2}{*}{ Year } & \multicolumn{5}{|c|}{ Total births } & \multicolumn{2}{|c|}{ All preterm births } & \multicolumn{2}{|c|}{ Mild preterm } & \multicolumn{2}{|c|}{ Moderate preterm } & \multicolumn{2}{|c|}{ Extreme preterm } \\
\hline & $\begin{array}{l}\text { No of } \\
\text { births }\end{array}$ & $\begin{array}{c}\text { Maternal } \\
\text { age (years) }\end{array}$ & $\begin{array}{l}\text { Birth weight } \\
\text { (g) }\end{array}$ & $\begin{array}{c}\% \\
\text { SGA }\end{array}$ & $\begin{array}{c}\% \\
\text { LBW }\end{array}$ & $\begin{array}{c}\% \\
\text { Rate }\end{array}$ & $\begin{array}{l}\text { Birth weight } \\
\text { (g) }\end{array}$ & $\begin{array}{c}\% \\
\text { Rate }\end{array}$ & $\begin{array}{l}\text { Birth weight } \\
\text { (g) }\end{array}$ & $\begin{array}{c}\% \\
\text { Rate }\end{array}$ & $\begin{array}{l}\text { Birth weight } \\
\text { (g) }\end{array}$ & $\begin{array}{c}\% \\
\text { Rate }\end{array}$ & $\begin{array}{l}\text { Birth weight } \\
\text { (g) }\end{array}$ \\
\hline \multicolumn{14}{|c|}{ Spontaneous delivery } \\
\hline 2002 & 38658 & $\begin{array}{c}29.3 \\
(23.3-35.3)\end{array}$ & $\begin{array}{c}3320 \\
(2690-3910)\end{array}$ & 10.98 & 5.63 & 7.41 & $\begin{array}{c}2510 \\
(1480-3170)\end{array}$ & 5.81 & $\begin{array}{c}2650 \\
(2120-3230)\end{array}$ & 0.79 & $\begin{array}{c}1985 \\
(1390-2480)\end{array}$ & 0.82 & $\begin{array}{c}1220 \\
(750-1795)\end{array}$ \\
\hline 2003 & 38990 & $\begin{array}{c}29.4 \\
(23.3-35.4)\end{array}$ & $\begin{array}{c}3318 \\
(2690-3910) \\
\end{array}$ & 10.49 & 5.69 & 7.42 & $\begin{array}{c}2520 \\
(1535-3130)\end{array}$ & 5.90 & $\begin{array}{c}2650 \\
(2100-3190)\end{array}$ & 0.78 & $\begin{array}{c}1940 \\
(1440-2460)\end{array}$ & 0.74 & $\begin{array}{c}1195 \\
(740-1793)\end{array}$ \\
\hline 2004 & 42077 & $\begin{array}{c}29.4 \\
(23.5-35.6)\end{array}$ & $\begin{array}{c}3330 \\
(2705-3920)\end{array}$ & 9.92 & 5.50 & 7.52 & $\begin{array}{c}2550 \\
(1495-3180)\end{array}$ & 5.83 & $\begin{array}{c}2680 \\
(2110-3240)\end{array}$ & 0.79 & $\begin{array}{c}1990 \\
(1490-2485)\end{array}$ & 0.89 & $\begin{array}{c}1250 \\
(732-1800)\end{array}$ \\
\hline 2005 & 43290 & $\begin{array}{c}29.4 \\
(23.6-35.7)\end{array}$ & $\begin{array}{c}3330 \\
(2705-3920)\end{array}$ & 10.15 & 5.39 & 7.38 & $\begin{array}{c}2520 \\
(1470-3170)\end{array}$ & 5.80 & $\begin{array}{c}2655 \\
(2090-3250)\end{array}$ & 0.76 & $\begin{array}{c}1963 \\
(1483-2435)\end{array}$ & 0.82 & $\begin{array}{c}1160 \\
(715-1700)\end{array}$ \\
\hline 2006 & 45003 & $\begin{array}{c}29.4 \\
(23.6-35.8)\end{array}$ & $\begin{array}{c}3330 \\
(2700-3925)\end{array}$ & 9.82 & 5.32 & 7.36 & $\begin{array}{c}2540 \\
(1530-3140)\end{array}$ & 5.74 & $\begin{array}{c}2660 \\
(2100-3200)\end{array}$ & 0.85 & $\begin{array}{c}1940 \\
(1475-2.400)\end{array}$ & 0.76 & $\begin{array}{c}1250 \\
(720-1735)\end{array}$ \\
\hline 2007 & 46276 & $\begin{array}{c}29.4 \\
(23.6-35.8) \\
\end{array}$ & $\begin{array}{c}3330 \\
(2720-3920) \\
\end{array}$ & 9.83 & 5.12 & 6.93 & $\begin{array}{c}2520 \\
(1511-3145) \\
\end{array}$ & 5.37 & $\begin{array}{c}2655 \\
(2140-3200) \\
\end{array}$ & 0.79 & $\begin{array}{c}1995 \\
(1490-2450)\end{array}$ & 0.77 & $\begin{array}{c}1210 \\
(740-1775) \\
\end{array}$ \\
\hline 2008 & 47893 & $\begin{array}{c}29.5 \\
(23.6-35.9) \\
\end{array}$ & $\begin{array}{c}3345 \\
(2720-3940) \\
\end{array}$ & 9.24 & 5.22 & 7.15 & $\begin{array}{c}2510 \\
(1510-3130)\end{array}$ & 5.58 & $\begin{array}{c}2650 \\
(2110-3200) \\
\end{array}$ & 0.78 & $\begin{array}{c}1990 \\
(1490-2400) \\
\end{array}$ & 0.79 & $\begin{array}{c}1250 \\
(712-1850) \\
\end{array}$ \\
\hline 2009 & 48237 & $\begin{array}{c}29.5 \\
(23.6-35.9)\end{array}$ & $\begin{array}{c}3345 \\
(2720-3940)\end{array}$ & 9.69 & 5.15 & 6.98 & $\begin{array}{c}2515 \\
(1480-3150)\end{array}$ & 5.38 & $\begin{array}{c}2660 \\
(2120-3220)\end{array}$ & 0.82 & $\begin{array}{c}1984 \\
(1380-2400)\end{array}$ & 0.78 & $\begin{array}{c}1240 \\
(750-1795)\end{array}$ \\
\hline 2010 & 49166 & $\begin{array}{c}29.7 \\
(23.8-35.9)\end{array}$ & $\begin{array}{c}3350 \\
(2730-3940)\end{array}$ & 9.24 & 4.85 & 6.84 & $\begin{array}{c}2530 \\
(1470-3135)\end{array}$ & 5.28 & $\begin{array}{c}2655 \\
(2120-3200)\end{array}$ & 0.76 & $\begin{array}{c}1980 \\
(1470-2470)\end{array}$ & 0.81 & $\begin{array}{c}1220 \\
(705-1770)\end{array}$ \\
\hline 2011 & 48930 & $\begin{array}{c}29.7 \\
(23.8-36.0)\end{array}$ & $\begin{array}{c}3350 \\
(2730-3940)\end{array}$ & 9.62 & 4.89 & 6.80 & $\begin{array}{c}2510 \\
(1450-3145)\end{array}$ & 5.26 & $\begin{array}{c}2660 \\
(2120-3220)\end{array}$ & 0.72 & $\begin{array}{c}1963 \\
(1405-2418)\end{array}$ & 0.82 & $\begin{array}{c}1240 \\
(720-1765)\end{array}$ \\
\hline Total & 448520 & $\begin{array}{c}29.5 \\
(23.6-35.8)\end{array}$ & $\begin{array}{c}3335 \\
(2710-3930)\end{array}$ & 9.86 & 5.26 & 7.16 & $\begin{array}{c}2520 \\
(1490-3150)\end{array}$ & 5.58 & $\begin{array}{c}2660 \\
(2115-3215)\end{array}$ & 0.78 & $\begin{array}{c}1975 \\
(1448-2430)\end{array}$ & 0.80 & $\begin{array}{c}1220 \\
(730-1780)\end{array}$ \\
\hline \multicolumn{14}{|c|}{ Overall delivery } \\
\hline 2002 & 55275 & $\begin{array}{c}29.3 \\
(23.2-35.3)\end{array}$ & $\begin{array}{c}3350 \\
(2730-3950)\end{array}$ & 10.74 & 4.91 & 5.99 & $\begin{array}{c}2520 \\
(1540-3180)\end{array}$ & 4.74 & $\begin{array}{c}2650 \\
(2100-3250)\end{array}$ & 0.59 & $\begin{array}{c}1970 \\
(1390-2460)\end{array}$ & 0.61 & $\begin{array}{c}1220 \\
(750-1790)\end{array}$ \\
\hline 2003 & 55639 & $\begin{array}{c}29.3 \\
(23.2-35.4)\end{array}$ & $\begin{array}{c}3350 \\
(2720-3950)\end{array}$ & 10.34 & 4.89 & 5.98 & $\begin{array}{c}2530 \\
(1600-3140)\end{array}$ & 4.84 & $\begin{array}{c}2640 \\
(2090-3200)\end{array}$ & 0.59 & $\begin{array}{c}1940 \\
(1440-2460)\end{array}$ & 0.55 & $\begin{array}{c}1200 \\
(740-1790)\end{array}$ \\
\hline 2004 & 58041 & $\begin{array}{c}29.4 \\
(23.4-35.7)\end{array}$ & $\begin{array}{c}3360 \\
(2740-3960)\end{array}$ & 9.90 & 4.87 & 6.26 & $\begin{array}{c}2555 \\
(1540-3180)\end{array}$ & 4.96 & $\begin{array}{c}2680 \\
(2100-3240)\end{array}$ & 0.62 & $\begin{array}{c}1990 \\
(1490-2493)\end{array}$ & 0.68 & $\begin{array}{c}1250 \\
(730-1800)\end{array}$ \\
\hline 2005 & 59368 & $\begin{array}{c}29.4 \\
(23.5-35.7) \\
\end{array}$ & $\begin{array}{c}3360 \\
(2740-3960) \\
\end{array}$ & 10.08 & 4.73 & 6.19 & $\begin{array}{c}2535 \\
(1510-3180) \\
\end{array}$ & 4.96 & $\begin{array}{c}2660 \\
(2080-3260) \\
\end{array}$ & 0.61 & $\begin{array}{c}1970 \\
(1490-2450) \\
\end{array}$ & 0.62 & $\begin{array}{c}1160 \\
(713-1700) \\
\end{array}$ \\
\hline 2006 & 60871 & $\begin{array}{c}29.4 \\
(23.5-35.8)\end{array}$ & $\begin{array}{c}3360 \\
(2730-3960)\end{array}$ & 9.81 & 4.73 & 6.16 & $\begin{array}{c}2540 \\
(1560-3155)\end{array}$ & 4.90 & $\begin{array}{c}2660 \\
(2090-3210)\end{array}$ & 0.66 & $\begin{array}{c}1935 \\
(1470-2400)\end{array}$ & 0.60 & $\begin{array}{c}1260 \\
(720-1740)\end{array}$ \\
\hline 2007 & 61847 & $\begin{array}{c}29.4 \\
(23.5-35.9) \\
\end{array}$ & $\begin{array}{c}3360 \\
(2740-3960)\end{array}$ & 9.77 & 4.64 & 5.86 & $\begin{array}{c}2520 \\
(1560-3145)\end{array}$ & 4.61 & $\begin{array}{c}2650 \\
(2120-3200)\end{array}$ & 0.64 & $\begin{array}{c}1990 \\
(1480-2430)\end{array}$ & 0.61 & $\begin{array}{c}1210 \\
(740-1770)\end{array}$ \\
\hline 2008 & 63999 & $\begin{array}{c}29.5 \\
(23.5-36.0) \\
\end{array}$ & $\begin{array}{c}3370 \\
(2750-3980)\end{array}$ & 9.30 & 4.69 & 6.11 & $\begin{array}{c}2520 \\
(1550-3145)\end{array}$ & 4.84 & $\begin{array}{c}2650 \\
(2100-3210)\end{array}$ & 0.63 & $\begin{array}{c}1990 \\
(1490-2410)\end{array}$ & 0.63 & $\begin{array}{c}1255 \\
(710-1850) \\
\end{array}$ \\
\hline 2009 & 63415 & $\begin{array}{c}29.5 \\
(23.5-36.0) \\
\end{array}$ & $\begin{array}{c}3370 \\
(2740-3975)\end{array}$ & 9.71 & 4.74 & 6.07 & $\begin{array}{c}2520 \\
(1528-3150)\end{array}$ & 4.77 & $\begin{array}{c}2655 \\
(2090-3220)\end{array}$ & 0.67 & $\begin{array}{c}1980 \\
(1385-2400)\end{array}$ & 0.63 & $\begin{array}{c}1240 \\
(750-1798)\end{array}$ \\
\hline 2010 & 64372 & $\begin{array}{c}29.6 \\
(23.7-36.0)\end{array}$ & $\begin{array}{c}3375 \\
(2750-3980)\end{array}$ & 9.43 & 4.59 & 5.98 & $\begin{array}{c}2530 \\
(1520-3135)\end{array}$ & 4.69 & $\begin{array}{c}2650 \\
(2090-3195)\end{array}$ & 0.65 & $\begin{array}{c}1975 \\
(1470-2465)\end{array}$ & 0.64 & $\begin{array}{c}1220 \\
(705-1770)\end{array}$ \\
\hline 2011 & 64050 & $\begin{array}{c}29.7 \\
(23.8-36.0)\end{array}$ & $\begin{array}{c}3370 \\
(2750-3980)\end{array}$ & 9.65 & 4.52 & 5.88 & $\begin{array}{c}2510 \\
(1490-3155)\end{array}$ & 4.62 & $\begin{array}{c}2650 \\
(2090-3220)\end{array}$ & 0.61 & $\begin{array}{c}1955 \\
(1400-2408)\end{array}$ & 0.65 & $\begin{array}{c}1240 \\
(712-1765)\end{array}$ \\
\hline Total & 606877 & $\begin{array}{c}29.5 \\
(23.5-35.8)\end{array}$ & $\begin{array}{c}3360 \\
(2740-3965)\end{array}$ & 9.85 & 4.73 & 6.04 & $\begin{array}{c}2530 \\
(1540-3155)\end{array}$ & 4.79 & $\begin{array}{c}2650 \\
(2100-3220)\end{array}$ & 0.63 & $\begin{array}{c}1970 \\
(1450-2430)\end{array}$ & 0.62 & $\begin{array}{c}1220 \\
(725-1780)\end{array}$ \\
\hline
\end{tabular}

$\mathrm{SGA}=$ Small for gestational age. LBW = Low birth weight $(<2500 \mathrm{~g})$.

Preterm categories: mild $=34-36$ weeks gestation, moderate $=32-33$ weeks, extreme $=<32$ weeks.

Parity was constant over the study period: median $(10-90$ th centile $)=2(1-3)$. 
Table 2| Percentage change in risk of preterm delivery in association with the successive implementation of public smoking bans. Values are percentage change $(95 \% \mathrm{Cl})$

\begin{tabular}{|c|c|c|c|c|c|c|}
\hline \multirow[b]{2}{*}{ Model } & \multicolumn{2}{|c|}{ Legislation 2006} & \multicolumn{2}{|c|}{ Legislation 2007} & \multicolumn{2}{|c|}{ Legislation 2010} \\
\hline & Step change $¥$ & Slope change§ & Step change $¥$ & Slope change§ & Step change $\neq$ & Slope change§ \\
\hline \multicolumn{7}{|c|}{ Spontaneous preterm delivery } \\
\hline $2006 \dagger$ & $\begin{array}{c}-3.24(-4.40 \text { to } \\
-2.07)^{\star}\end{array}$ & $\begin{array}{c}-1.85(-2.42 \text { to } \\
-1.28)^{*}\end{array}$ & $\mathrm{~N} / \mathrm{A}$ & $\mathrm{N} / \mathrm{A}$ & $\mathrm{N} / \mathrm{A}$ & $\mathrm{N} / \mathrm{A}$ \\
\hline $2007 \dagger$ & $\mathrm{N} / \mathrm{A}$ & $\mathrm{N} / \mathrm{A}$ & $\begin{array}{c}-3.69(-4.81 \text { to } \\
-2.55)^{*}\end{array}$ & $\begin{array}{c}-2.16(-2.85 \text { to } \\
-1.46)^{\star}\end{array}$ & $\mathrm{N} / \mathrm{A}$ & $\mathrm{n} / \mathrm{a}$ \\
\hline $2010 \dagger$ & $\mathrm{N} / \mathrm{A}$ & $\mathrm{N} / \mathrm{A}$ & N/A & $\mathrm{N} / \mathrm{A}$ & $\begin{array}{c}-3.36(-4.73 \text { to } \\
-1.98)^{*}\end{array}$ & $\begin{array}{c}-5.17(-7.36 \text { to } \\
-2.94)^{*}\end{array}$ \\
\hline Final & - & - & $\begin{array}{c}-3.13(-4.37 \text { to } \\
-1.87)^{\star}\end{array}$ & - & - & $\begin{array}{c}-2.65(-5.11 \text { to } \\
-0.13)^{\star}\end{array}$ \\
\hline \multicolumn{7}{|c|}{ Overall preterm delivery } \\
\hline $2006+$ & $\begin{array}{c}-0.59(-2.63 \text { to } \\
1.49)\end{array}$ & $\begin{array}{c}-1.95(-3.50 \text { to } \\
-0.37)^{\star}\end{array}$ & $\mathrm{N} / \mathrm{A}$ & $\mathrm{N} / \mathrm{A}$ & $\mathrm{N} / \mathrm{A}$ & $\mathrm{N} / \mathrm{A}$ \\
\hline $2007 \dagger$ & $\mathrm{N} / \mathrm{A}$ & $\mathrm{N} / \mathrm{A}$ & $\begin{array}{c}-2.28(-4.37 \text { to } \\
-0.15)^{*}\end{array}$ & $\begin{array}{c}-1.42(-2.87 \text { to } \\
0.05)^{\star \star}\end{array}$ & $\mathrm{N} / \mathrm{A}$ & $\mathrm{N} / \mathrm{A}$ \\
\hline $2010 \dagger$ & $\mathrm{N} / \mathrm{A}$ & $\mathrm{N} / \mathrm{A}$ & $\mathrm{N} / \mathrm{A}$ & $\mathrm{N} / \mathrm{A}$ & $\begin{array}{c}-1.24(-3.05 \text { to } \\
0.60)\end{array}$ & $\begin{array}{c}-2.10(-4.82 \text { to } \\
0.69)\end{array}$ \\
\hline Final & - & - & $\begin{array}{c}-3.18(-5.38 \text { to } \\
-0.94)^{*}\end{array}$ & - & - & $\begin{array}{c}-3.50(-6.35 \text { to } \\
-0.57)^{*}\end{array}$ \\
\hline
\end{tabular}

Percentage change based on odds ratios derived from logistic regression models and adjusted for underlying trend, newborn sex, maternal age, parity, socioeconomic status, urbanisation, calendar month, day of the week, public holidays, influenza epidemics, and short term changes in apparent temperature and particulate air pollution $\left(\mathrm{PM}_{10}\right)$. Final models were obtained by including the three step changes and the three slope changes in one model and then removing the least significant factors one at a time.

${ }^{*} \mathrm{P}<0.05 ;{ }^{* *} \mathrm{P}<0.1$.

†Single-legislation models including either the step change or the slope change into the model.

$\ddagger$ Step change at 1 January 2006 (legislation 2006), 1 January 2007 (legislation 2007), or 1 January 2010 (legislation 2010). §Slope change after 1 January 2006 (legislation 2006), 1 January 2007 (legislation 2007), or 1 January 2010 (legislation 2010 ).

$\mathrm{N} / \mathrm{A}=$ Not applicable 


\section{Figure}

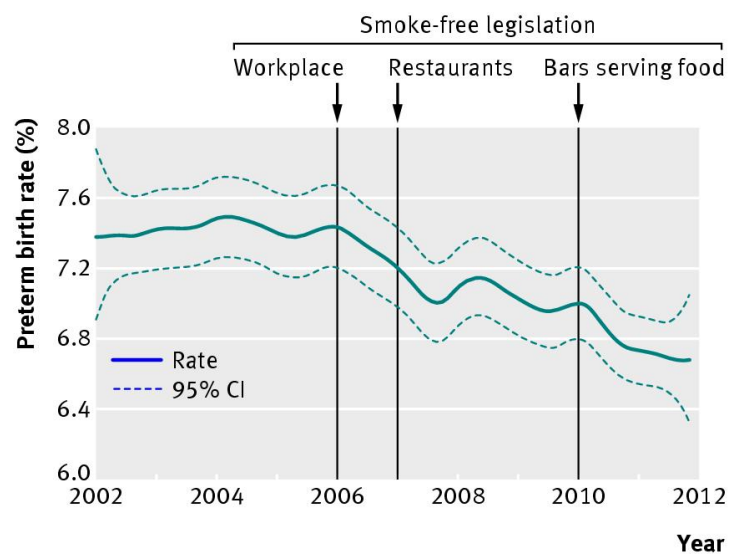

Time trend in rate of spontaneous preterm deliveries (with 95\% confidence interval) in Flanders, 2002-11, with vertical lines indicating stepwise implementation of smoke-free legislation 